\title{
The Declining Role of Western Europe in Shipping and Shipbuilding, 1900-2000

\author{
Stig Tenold
}

\section{Introduction}

During the twentieth century, and in particular in the period after 1970, Western Europe lost its hegemony in international shipping and shipbuilding. The aim of this chapter is to present this decline, and to discuss its basis. The reduction of the European position was a necessary condition for the international spread - the globalization-of shipping and shipbuilding after World War II.

The chapter consists of three sections. In the first section, Western Europe's dominant position in world shipping and shipbuilding at the start of the twentieth century is presented. Among the factors that are emphasized to explain the hegemony are Europe's (and, in particular, the UK's) leading position within global production, trade and politics; the

S. Tenold ( $₫)$

Department of Economics, NHH - Norwegian

School of Economics, Bergen, Norway

e-mail: stig.tenold@nhh.no 
superior access to technology and capital; and the cost structure within shipping.

Starting with a quantification of the reduction in the role of Western European countries in world shipping and shipbuilding, the second section of the chapter suggests some factors that can explain the diminishing position. This analysis follows the scheme used in Stanley Sturmey's examination of the decline of the British-registered fleet from 1900 to 1960 in his classic book British Shipping and World Competition. Four factors are considered; competitiveness, subsidies, random factors and internal (business) constraints in European shipping and shipbuilding companies. ${ }^{1}$

In his analysis of British shipping, Sturmey largely exonerated the first three factors. He primarily blamed British shipowners and their commercial lethargy for the fleet's decline. The analysis in this paper shows that when we consider the relative reduction of European shipping and shipbuilding as a whole, and extend the time frame to include all of the twentieth century, the other factors take on a much more prominent role. Moreover, the manner in which the shipping industry adapted to, and partly stemmed, the decline, was different from what occurred within shipbuilding.

The final section of the chapter discusses the timing of the transformation of the maritime industry. At the start of the twentieth century, and even in the first years after World War II, the European position should be considered 'abnormally strong'. In the first post-war decades, the hegemony was increasingly challenged. However, a combination of defensive national policies and technological limitations initially muted the decline both within shipping and within shipbuilding. Towards the end of the century, we see that the developments of these two maritime sectors diverged.

In shipping, the manner in which the industry was organized became totally transformed, and the question of nationality became very elusive. Still, behind this veil of stateless business, European capital and competence continued to play a crucial, albeit reduced, role. Within shipbuilding, however, Asian shipyards had managed to acquire a dominance that was similar in scale to the European leadership 100 years earlier.

${ }^{1}$ Sturmey $(1962 / 2010,1-2)$. 


\section{The Starting Point-The European Hegemony}

Today, particularly with regard to manufacturing production, the world appears to be borderless and 'global'. Distances used to pose a problem for businesses - in terms of communication and transport costs, and in particular in terms of 'time costs'. This is no longer the case. From the perspective of an enterprise at the start of the twentieth century, transport and communication today would seem unbelievably fast and inexpensive. Information, commodities and products move rapidly, all over the globe. With this current context as the starting point, it may be difficult to fathom how 'European' most of the maritime industry was around the year 1900.

The establishment and growth of the international economy during the nineteenth century had primarily been a European endeavour. ${ }^{2}$ Of course, the economic integration with other parts of the world (North America, in particular, but also the other continents) was the defining factor of this 'first era of globalization'. However, it happened largely on European terms, on European keels and with European capital and technology. The only area that had provided a short-lived challenge to the European maritime dominance-the North-American continent—preferred landward expansion and during the last decades of the nineteenth century gradually built down its presence within shipping and shipbuilding. ${ }^{3}$

Europe determined the scale, the scope and the speed of the world maritime industries, and nowhere was this more evident than in the case of the United Kingdom.

In 1900 the global shipbuilding industry had two centres: The Clyde and The Tyne and Wear-region - the west of Scotland and the northeast

\footnotetext{
${ }^{2}$ This paragraph can — rightly — be criticized for being Eurocentric. However, such an orientation is not 'wrong', as developments in intercontinental shipping to such a large degree had their basis in Europe. There were of course important and interesting maritime connections and expansion in other parts of the world. Yet, when we look at the construction of ocean-going ships and the ownership of the world fleet, the data show European market shares of more than $90 \%$ - confer Figure 1 and Table 1. It would thus be misguided to put the main emphasis elsewhere.

${ }^{3}$ With regard to the US 'withdrawal', the initial economic explanation-profits were higher on land than at sea-was shortly after World War I given a political justification as well. 'The Jones Act'formally the Merchant Marine Act of 1920-imposed restrictions that ensured that US shipping could not possibly be competitive, and thus profitable, in the international market, at least for new ships flying the American flag.
} 
of England. ${ }^{4}$ More than $70 \%$ of the world's steamship fleet at that time had been produced in the United Kingdom, and most alternatives to British-built ships were relatively expensive, technologically inferior vessels that found willing buyers mainly as a result of nationalistic attitudes or government initiatives. ${ }^{5}$

The basis for the strong position of UK shipyards was primarily technological; The Industrial Revolution had given them a first-mover advantage that lasted well into the twentieth century. The UK had the right combination of capital and competence-both skilled and unskilled labour-and could take advantage of their technological lead. Moreover, the country's shipbuilding industry had the size that was necessary to fully utilize the economies of scale in both steel and ship production. ${ }^{6}$

In the period 1901-1905, British yards produced almost $60 \%$ of the world's new shipping tonnage. As Pollard points out, this market share underestimates the British position, due to the fact that 'the tonnage launched in the United Kingdom was of a higher quality, ton for ton, than that of the rest of the world'. 'Although the United States was the second-largest producer, the European market share was close to $85 \%$ of the market for merchant ships. However, much of the non-British production was subsidized; 'Britain kept her share of the world market because few of the shipyards abroad were truly competitive'. 8 This was particularly evident with regard to labour productivity; annual output per shipyard worker in the UK was 12.5 tons at the start of the century, the United States came second with 6.8 tons and Germany third with 3.3 tons. For France and Holland, the figure was less than

\footnotetext{
${ }^{4}$ In 1911-1912, yards on the Tyne and the Wear produced around 35\% of the UK output, while yards on the Clyde produced 31.5\%; data from Fairplay in Slaven $(2013,51)$.

${ }^{5}$ Calculated on the basis of Table 4 in Lloyd's Register (1901, supplement, 758-759). The followers were Germany with $6.8 \%$, the United States with $6.5 \%$ and Sweden with $4.3 \%$. See also Schwarz and von Halle (1902), quoted in Pollard (1957, 428).

${ }^{6}$ At times, British yards also benefitted from US steel producers dumping steel abroad; Pollard (1957, 439).

${ }^{7}$ Pollard $(1957,426)$. Calculations based on data from Lloyd's. Though the $60 \%$ market share was impressive, it was down almost 20 percentage points relative to the period 1892-1896. For a statistical presentation of the development of British shipbuilding, see Buxton et al. (2015).

${ }^{8}$ Pollard $(1957,431)$.
} 


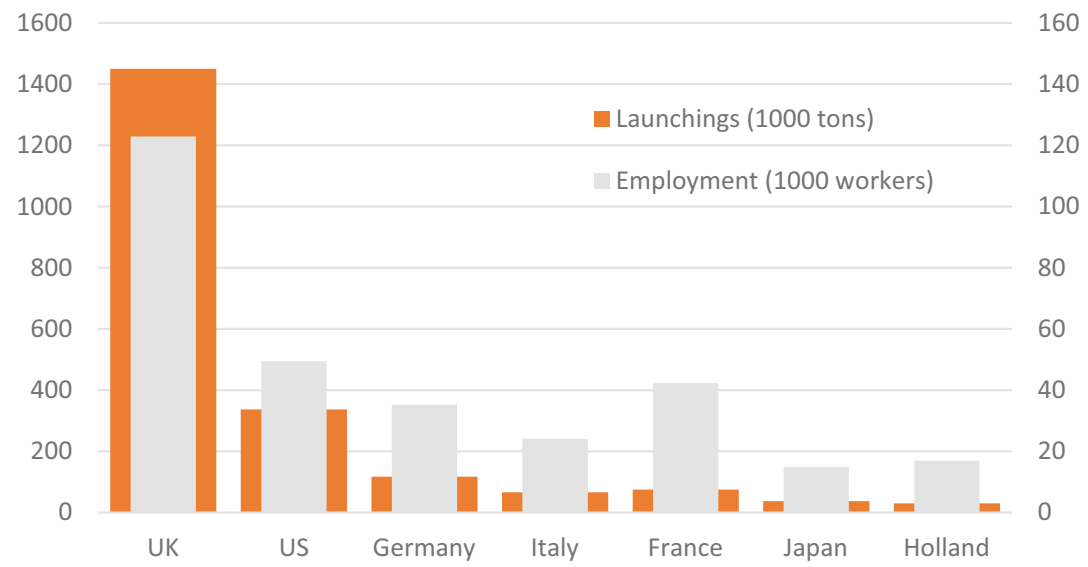

Fig. 2.1 World shipbuilding around the turn of the century-production (1000 tons, left axis) and employment (1000 men, right axis) (Chart based on Board of Trade data in Pollard [1957, 438], referring to five-year averages around the following specific years: 1895 [Germany]; 1896 [France]; 1899 [Holland]; 1900 [US]; 1901 [UK and Italy] and 1902 [Japan])

two. ${ }^{9}$ Figure 2.1 shows shipbuilding production and employment around the turn of the century.

Shipbuilders in the UK derived an undisputed advantage from their proximity to the principal market for ships: British shipowners. By 1900, the British owners controlled around half of the world fleet, and almost $55 \%$ of the new steamships delivered that year went to British owners. ${ }^{10}$ British shipping companies had been pioneers in the long-lasting transformation from sail to steam and from wood to iron and then steel hulls, and they were loyal to British yards. In 1900 four ships from Dutch yards were added to the British fleet; they were the only foreign-built newbuildings that year. The previous year there had been none. ${ }^{11}$ Having the world's major shipowners as 'captive customers' clearly helped British shipbuilding, at least in the short term.

\footnotetext{
${ }^{9}$ Board of Trade data in Pollard $(1957,438)$. The classic article on the gradual decline of the British superiority is Lorenz (1991). For more extensive discussions, confer Slaven (2013) or Johnman and Murphy (2002).

${ }^{10}$ Calculated on the basis of Table 7 in Lloyd's Register 1901, supplement, 764-765.

${ }^{11}$ Lloyd's Register 1901, supplement, Table 3, 756-757 and Table 7, 764-765.
} 
As Robertson points out in his article on the Scottish shipbuilding and shipping company William Denny and Brothers, 'close financial ties between shipbuilders and shipowners were common in the second half of the nineteenth century'. ${ }^{12}$ Such relationships continued to be widespread and important also after the turn of the century. This symbiosis between shipbuilders and shipowners reflected, but initially also strengthened, the British advantage. Standardization-long series of identical ships-information and knowledge exchange, as well as intergroup loans that could even out cash flow fluctuations, improved the competitiveness of both shipbuilders and shipping companies. Often the two groups converged, such as in the case of Furness Withy. ${ }^{13}$

Within shipping, the concentration was lower than within shipbuilding and the UK presence not as dominant. Other countries — primarily within Europe-had managed to build up market shares in areas where they had political or colonial control. Alternatively-in the case of shipowners from less 'territorial' nations such as Greece and the Scandinavian countriesthey had managed to acquire important positions in certain niche markets. Still, the UK in general, and London in particular, continued to play crucial roles as the centre of a global system of shipping.

As world historians like to remind us, there were of course similar trading, financial and political hubs in other parts of the world. However, with regard to global trade-the intercontinental voyages, whose strong growth distinguishes the second half of the nineteenth century from previous periods - London was the undisputed engine. At this time, more than fifty per cent of the world merchant marine was registered in the UK, and

\footnotetext{
${ }^{12}$ Robertson $(1974,36)$.

${ }^{13}$ For a good schematic overview of the closeness of the links between shipowners and yards, see Boyce (1995, 181-182), and specifically on Furness Withy, Boyce (2012b). A similar, but slightly different, type of relation is seen in the case of the shipbuilders John Scott \& Co., who 'built and helped finance ships' for Alfred Holt \& Co. (Ocean Steam Ship Co.). Milne (2009, 19) argues that 'the shipowner-shipbuilder link was crucial to expanding shipping firms'. It could, however, be argued that the symbiosis subsequently turned from positive to negative. Conservative British shipowners did not encourage the country's yards to transform production from ships running on coal, of which they had plenty, to ships with diesel engines. Similarly, British yards with outdated thoughts about technology did not facilitate a shift from steam to motor ships in the country's fleet. The neighbourhood or cluster effect-positive in good times, detrimental in bad times-is one of the main arguments used to explain the problems of British shipbuilders in Todd (2011). See also Ingram and Lifschitz (2006) on the relations among various shipbuilders and between the shipyards and their subcontractors.
} 
the British fleet had more of the modern steamship tonnage than the rest of the nations combined.

Table 2.1 shows the distribution of the world fleet at the start of the twentieth century. The first columns show the sailing and steamship fleets, respectively, while the third column shows the 'Estimated' or 'Compensated' tonnage-a measure that takes into account differences in productivity between the two dominant technologies. As such, it is the best measure of the carrying capacity of the various countries' merchant marines. The fourth column shows the share of steam tonnage in the various fleets, and clearly illustrates that the transformation from sail to steam progressed at very different speeds in different countries.

The final column in Table 2.1 shows the countries' tonnage, divided by the number of inhabitants. This figure can be seen as a measure of the extent to which the countries had channelled their resources into the

Table 2.1 The world fleet of leading countries, $1900^{\mathrm{a}}$

\begin{tabular}{lcccll}
\hline & $\begin{array}{l}\text { Sail tons } \\
(\mathrm{t})\end{array}$ & $\begin{array}{l}\text { Steam } \\
\text { tons }(\mathrm{t})\end{array}$ & $\begin{array}{l}\text { Estimated } \\
\text { tons }(\mathrm{t})\end{array}$ & $\begin{array}{l}\text { Steam } \\
\text { share (\%) }\end{array}$ & $\begin{array}{l}\text { Tons per } \\
\text { inhabi- } \\
\text { tant }\end{array}$ \\
\hline GB \& Ireland & 1923 & 7150 & 27,663 & 78.8 & 0.667 \\
Germany & 558 & 1347 & 5407 & 70.7 & 0.096 \\
The United States & 1405 & 938 & 4782 & 40.0 & 0.063 \\
Norway & 930 & 499 & 2725 & 34.9 & 1.227 \\
France & 394 & 597 & 2543 & 60.2 & 0.066 \\
Italy & 483 & 374 & 1830 & 43.6 & 0.056 \\
Spain & 91 & 435 & 1657 & 82.7 & 0.091 \\
Japan & 148 & 330 & 1336 & 69.0 & 0.031 \\
Sweden & 256 & 257 & 1181 & 50.1 & 0.230 \\
Br. Australia & 164 & 234 & 1006 & 58.8 & 0.182 \\
Denmark & 111 & 245 & 993 & 68.8 & 0.405 \\
The Netherlands & 68 & 252 & 949 & 78.8 & 0.186 \\
Br. America & 446 & 103 & 817 & 18.8 & 0.109 \\
Russia & 152 & 173 & 774 & 53.2 & 0.007 \\
Greece & 176 & 165 & 770 & 48.4 & 0.298 \\
Other European & 336 & 424 & 1864 & 55.8 & \\
Other & 226 & 235 & 1072 & 50.1 & \\
$\quad$ non-European & & & & & \\
\hline Based & & & & \\
\hline
\end{tabular}

a Based on data from Statistics Norway (1902) Statistisk aarbog for kongeriget Norge (pp. 168-169). Kristiania: Det Statistiske Centralbureau and H. Aschehoug \& Co, Tables I and K. See Tenold $(2019,22-23)$, for a detailed presentation of the data 
shipping sector. When it comes to the relative importance of shipping, Norway is in a special position, where each inhabitant owned more than a ton of shipping tonnage. The United Kingdom, Denmark and Greece also had invested disproportionately in shipping. ${ }^{14}$

London's role as a global centre for trade and finance-which together with shipping were the dominant service industries - is an important explanation of the British hegemony. Around these service industries, a number of auxiliary businesses surfaced, gradually becoming more professionalized. The typical example of such a spin-off business would be Lloyd's, where the small beginnings in a coffee shop gradually evolved into one of the most important institutions in shipping's commercial infrastructure. ${ }^{15}$ Similarly, ship brokers, ship agents, banks, insurance companies and world-leading institutions such as The Baltic Mercantile and Shipping Exchange ensured the city's pre-eminence in global trade and shipping. 'The Baltic', for instance, 'acted as the unofficial regulator of the shipping business and significant segments of commodity trading' ${ }^{16}$

The pride of the British merchant marine was the elegant vessels that served British shipping lines around the globe. These shipping lines can be considered-in tandem with the telegraph network-as the tentacles of the empire; permanent connections that facilitated both the economic and the political role that the United Kingdom played in the global arena. By 1914 the submarine cables that Britain controlled were almost twice as large as those of the two next powers (The United States and France) combined, and the extensive telegraphic system contributed decisively to the City of London's position as the world capital of trade, shipping and finance. ${ }^{17}$ The shipping lines were to cargo transport what the telegraph was to information - a manifestation of British power, which contributed to preserving the very same dominance that it reflected.

Any explanation of the dominant European role within the maritime industries at a global level echoes the explanation of the British dominance

\footnotetext{
${ }^{14}$ Interestingly, three of these four countries-Denmark, Norway and Greece-are among the leading shipping nations even today, when we look at the size of their fleets relative to the countries' own needs.

${ }^{15}$ Boyce (2012a, 108-114).

${ }^{16}$ Boyce (2012a, 115).

${ }^{17}$ Scholl $(1998,201-202)$.
} 
at the European level. Key factors are the leading position within production and trade; the superior access to technology, capital and sufficiently skilled labour; and imperial ambitions and structures that ensured political support for maritime activities. Indeed, when we look more closely at the cost structure and the demands for competence within shipping, it is evident that there were few challengers outside Europe, even at the hypothetical level.

In shipping, success is defined by being internationally competitive. To succeed at the beginning of the twentieth century, a country needed funds to invest in tonnage, technological skills and competent labour to operate the vessels, as well as efficient commercial and political networks that could support shipping at home and abroad. It is evident that European countries had this - and that other parts of the world did not. Moreover, the UK satisfied these criteria better than the other European countries.

In international shipping, like in the case of industrialization and modernization more generally, Japan was the only contender outside Europe and its Western offshoots (The United States, Canada, Australia and New Zealand). This statement does not only pertain to the pre-twentiethcentury period, but rings true all the way until well after the Second World War. The combination of an outward-looking strategy and a fear of being colonized created a 'shipping-political complex' in Japan that spurred the growth of the country's fleet. ${ }^{18}$ Helped by the involuntary withdrawal of much European shipping during the First World War, Japanese shipping companies laid the foundation for a strong expansion in the interwar period. ${ }^{19}$

Within shipbuilding, the explanation of the European dominance was almost purely related to capital—not only 'capital' in its technological and its financial sense, but also in its human guise. Outside Europewith the exception of North America and Japan-the technology needed to produce large steam vessels was missing. Moreover, the funds necessary

\footnotetext{
${ }^{18}$ See Chida and Davies (2012) and Davies (2008).

${ }^{19}$ An early example of contra-factual thinking, from the British Board of Trade, reprinted in Berglund (1926, 647), suggests that the disruptions caused by the First World War reduced the fleets of the UK, Germany, Norway and France by 5 million, 3.5 million, 1 million and 500,000 tons, respectively. At the same time, 'the United States showed a gain of nearly 7,000,000 gross tons over her normal growth; and Japan 20,000 tons'.
} 
to establish shipyards capable of building such vessels were absent, as were the requisite knowledge and the needed skill base. Even the shipyards in the most advanced European countries had a productivity that was less than a third of the productivity in British yards around the turn of the century.

With regard to auxiliary services, closeness to the most important market — and to the informal institutions of shipping_-plays an important part. Gradually, the British way of doing business - the types of contracts, the accepted forms of insurance and the standardized clauses-became the established rules and regulations throughout the shipping market. Even today, the main framework covering maritime contracts is British, and agreements between businesses that have no relationship to the United Kingdom refer to British laws and institutions in the case of disagreement. The crucial role that was played by Western Europe/the United Kingdom/London in the development of the merchant economy and the transport and trade infrastructure undoubtedly casts long shadows, even after the dominance had disappeared.

\section{Lost Continent}

Europe's dominant position within shipping and shipbuilding was eroded throughout the twentieth century, though there appears to have been some acceleration towards the end of the millennium. Early challenges were related to the two wars. During these difficult years, the United States took over tasks within shipping and shipbuilding that the fighting European countries could no longer perform. Subsequently, and in particularly in the last decades of the twentieth century, the challenge came from the East. This time the competition was both stronger and more permanent.

The first warning shot came as early as the 1950s. Japan rose from the ashes of the Second World War to displace the UK as the world's leading shipbuilder in 1956. After the middle of the 1970s, South Korea and then China managed to grab massive market shares. At the beginning of the twenty-first century, the Asian presence in the high-volume shipbuilding 


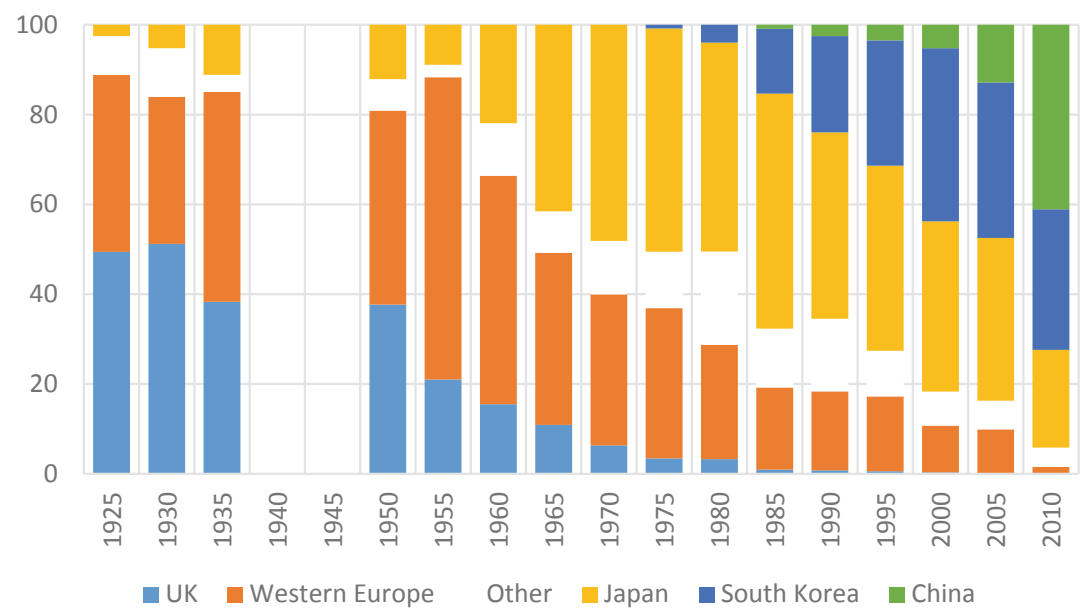

Fig. 2.2 Shares of world shipbuilding, per cent (Compiled on the basis of various issues of Lloyd's Statistical Tables. Based on Gross Register Tonnage, except for the 2010 figures which are based on Dead Weight Tonnage, and thus likely to slightly underestimate the European market shares. Although some countries are missing, the chart gives a representative overview of the shift)

market was even more dominant than Europe's had been one hundred years earlier. ${ }^{20}$

Figure 2.2 shows the spectacular decline in the European share of the world market for newbuildings after 1955. Moreover, it is clear that the hegemony was transferred to Asian yards, led by Japan, then followed by South Korea and China. By December 2008, only eight of the world's leading 100 yards, based on the size of the order book, were European. Some of these have subsequently closed down or have been taken over by other European or Asian yards. Given the dominant British position a century earlier, it is worth noting that not a single British yard warranted inclusion among the Top 100 shipbuilders in the world by 2008. The

\footnotetext{
${ }^{20}$ This is partly a matter of interpretation; in pure tonnage terms - measured as dead weight tons of shipping capacity produced or ordered - the three leading Asian shipbuilders (South Korea, Japan and China) were more dominant at the beginning of the twenty-first century than Europe had been at the beginning of the twentieth century. However, if we look at the value of the production, the continued construction of smaller high-technology vessels and luxury cruise ships at European yards skews the picture and increases the European share of the shipbuilding market.
} 
leading European yard - the German Meyer Werft—was number 38 on the list. At that time, the ten largest European yards had about three per cent of the total world order book-in sum less than half of what the world leading South Korean Hyundai group had. ${ }^{21}$

The shipbuilding hegemony moved from Europe to Asia during the twentieth century. In shipping the geographic shift has not been as pronounced. Moreover, changes in the manner in which the industry is organized make the transformation more difficult to quantify and identify. In some ways, many of the national traits within shipping were washed away during the twentieth century. This implies that while it is possible to identify a European decline, it is far more difficult to say something precise about where the business in fact moved.

At the start of the twentieth century, a ship's flag would reflect the nationality of the owners, the managers, the crew and officers and often the cargo owners as well. At the end of the twentieth century, it is usually the case that investors, managers, crews and officers come from different countries, and neither of these necessarily have any relationship to the flag that the ship is flying and the nationality of the owner of the cargo that it is carrying. For two-thirds of all merchant tonnage, the flag of the vessel reveals absolutely nothing about the real nationality of the main economic agents involved. Consequently, it is increasingly difficult to find a meaningful measure of 'the European share'.

The decline in Europe's share of the world fleet, as seen in Fig. 2.3, is clearly dramatic. At the same time, this occurred against a backdrop of reduced European importance in the international economy. Around 1900, the international economy-in terms of cross-border flows of trade and factors of production-was dominated by Western Europe. This region was responsible for more than three quarters of all manufacturing exports and more than two-thirds of the imports of primary products. ${ }^{22}$ Consequently, while the share of almost $97 \%$ of the world fleet was an overrepresentation, it to some extent reflected a real European dominance

\footnotetext{
${ }^{21}$ Based on data from ECORYS $(2009,55)$.

${ }^{22}$ Estimated on the basis of data for the United Kingdom and northwest Europe in Yates (1959), reprinted in Kenwood and Lougheed (1999, 84).
} 


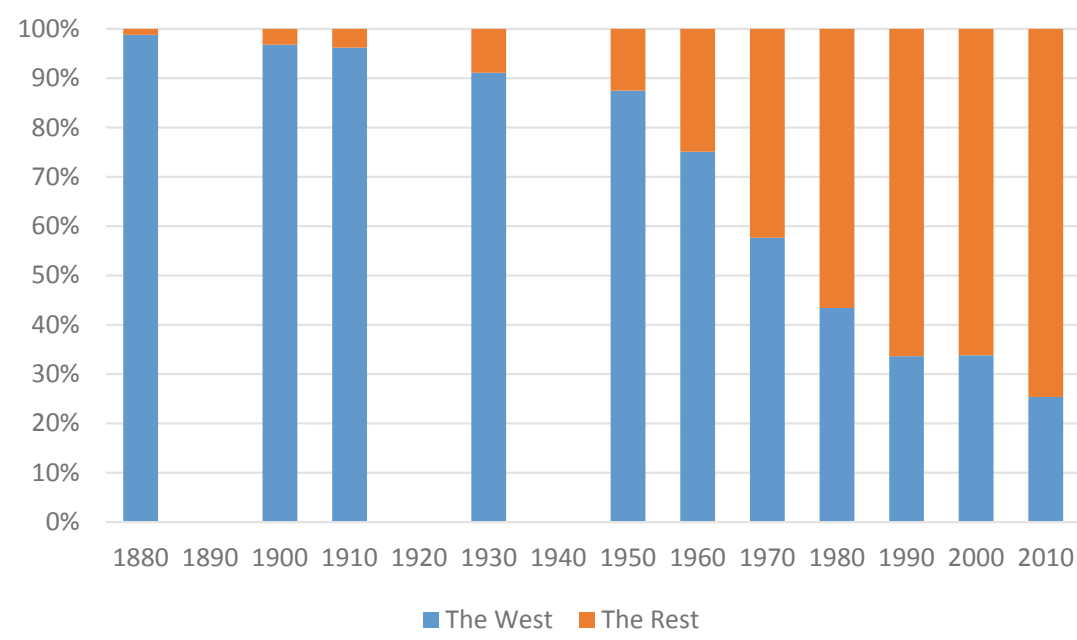

Fig. 2.3 Shares of the world fleet, per cent 1880-2010 (Based on a combination of definitions and sources from SSB, Lloyd's, UNCTAD and OECD. As the results are sensitive to the choice of tonnage measure, size restrictions and so on, this figure should be seen as an indication of the development, rather than as a precise measure)

in the international economy. While it is difficult to find comparable figures for the end of the twentieth century, it is evident that Western Europe's contribution to seaborne trade is far smaller. Data from the United Nations Conference on Trade and Development suggest that the Western European share of the volume of seaborne imports and exports in 2000 was less than a third and around a fifth, respectively. ${ }^{23}$

Table 2.2 is a good illustration of the manner in which the balance of international trade in general, and seaborne trade in particular, has shifted from Western Europe and the North-Atlantic economy to East and Southeast Asia. In 1910 more than half of the world's 15 busiest ports, measured by cargo volume, were European. By 2010 there was only one left. The United Kingdom had four ports in the Top 15 in 1910, and none 100 years later. It was little consolation that the country had four ports in the Top 100-Grimsby and Immingham at 68th, London at $82 \mathrm{nd}$, Milford Haven at 93rd and Southampton at 98th. In fact, the

${ }^{23}$ Calculated on the basis of data from 2000 in UNCTAD, Maritime Transport 2006, 133-136. 
Table 2.2 A comparison of the world's busiest ports, Top 151910 and 2010

\begin{tabular}{rlll}
\hline & $\begin{array}{l}\text { 1910-tons entered } \\
\text { and cleared }\end{array}$ & $\begin{array}{l}\text { 2010-total cargo } \\
\text { volume }\end{array}$ & 2010_container traffic \\
\hline 1 & New York & Shanghai & Shanghai \\
2 & Antwerp & Singapore & Singapore \\
3 & Hong Kong & Rotterdam & Hong kong \\
4 & Hamburg & Guangzho & Shenzhen \\
5 & London & Ningbo & Busan \\
6 & Shanghai & Tianjin & Ningbo-Zhouzhan \\
7 & Rotterdam & Qingdao & Guangzho \\
8 & Marseille & Qinhuangdao & Qingdao \\
9 & Cardiff & Hong Kong & Dubai \\
10 & Singapore & Busan & Rotterdam \\
11 & Constantinople & South Louisiana & Tianjin \\
12 & Liverpool & Houston & Kaohsiung \\
13 & Colombo & Shenzhen & Port Klang \\
14 & Tyne & Dalian & Antwerp \\
15 & Kobe & Port Hedland & Hamburg \\
\hline
\end{tabular}

aThe 1910-list has been calculated on the basis of Bureau of Statistics, 1911, 753; see the source for details. The 2010-lists are taken from American Association of Port Authorities, 2011

biggest British port in the year 2000, would have been number 12 on the list of Chinese ports or number 34 on a list of Asia's busiest ports.

The data in the charts and tables above clearly illustrate the reduced European role within shipping and shipbuilding. In order to discuss the basis for this decline, we will use the analytical framework in Stanley Sturmey's seminal book British Shipping and World Competition-which deals with the period from the start of the twentieth century to 1960 . Here, Sturmey presents four factors that might explain why the British share of the world fleet 'declined from over forty-five per cent of the world total in 1900 to about sixteen per cent of that total in 1960'. His possible culprits are (1) a transformation of the basis for the competitive situation, caused for instance by changes in the cost structure within shipping; (2) subsidies or other mechanisms that interfered with the competitive market mechanism; (3) random factors such as wars, changes in the trade pattern, taxation or non-shipping policies; and (4) internal constraints. ${ }^{24}$

\footnotetext{
${ }^{24}$ Sturmey (1962/2010, 1-2). There have of course been plenty of research and numerous public and privately commissioned reports dealing with the same problems. For an 'approved' explanation,
} 
Sturmey claims that in the case of British shipping, the first three factors were not unimportant, but 'neither separately nor together can these answers be regarded as more than partial'. ${ }^{25} \mathrm{He}$ finds that the main basis for the British decline was internal constraints-the attitudes of the industry-which fostered inadequate and inhibiting reactions to a changing shipping market. Contemporary sources concur-the problem was business decisions, rather than comparative advantage, macroeconomic developments, policy issues or random factors. This idea is supported by The Economist, which in the early 1960s suggested that British shipping companies committed 'suicide by commercial timidity and sheer bad judgment. ${ }^{26}$

It is not possible to magnify Stanley Sturmey's explanation of the British decline, give it a European setting, and claim that it is valid for all of the twentieth century. Even the British experience was diverse, and this variation increases even more when we look at the whole continent and extend the time period. At the same time, Sturmey's analysis can be very useful, as it provides us with a set of potential explanatory factors, and these can be applied to the longer and broader perspective.

Perhaps surprisingly, if we extend the basis for the analysis like this, Sturmey's explanations are turned on their heads. In the case of the decline of European shipping and shipbuilding during the twentieth century, the culprits are the factors that Sturmey largely dismissed. ${ }^{27}$ Internal constraints or business lethargy is not the main factor behind the European decline. In fact, for shipping, the result is quite the opposite; European shipping companies managed to adapt wisely to the new circumstances, but the other forces were too strong.

This finding is not necessarily in opposition to one of Sturmey's main arguments. He actually points out that it is exactly because of the improved

see UK Parliament (1987-1988) Transport Committee, First report: 'Decline in the UK-registered merchant fleet'. However, few-if any-studies have been as influential and systematic as that of Sturmey, which makes it a good starting point for the discussion.

${ }^{25}$ Sturmey (1962/2010, 328).

${ }^{26}$ The Economist, 9 February 1963, 519.

${ }^{27}$ Subsequent analyses, including Jamieson (2003), have a more nuanced view of British shipowners than Sturmey, pointing out that they succeeded in certain segments. 
competitive abilities and the successful strategic decisions in other countries - and his examples are primarily found in Europe - that the United Kingdom lost out in the years from 1900 to 1960. A similar contrast between under-geared British owners and their more expansive European cousins is made by Richard Goss, in his analysis of British shipping companies' business strategies in the post-war period. ${ }^{28}$ Elsewhere, Goss has pointed out the linkage between the decline and non-shipping policies, for instance, the manner in which governments supported and subsidized industries that competed with shipping. All things equal, such preference is likely to reduce the role of shipping. ${ }^{29}$

\section{European Shipping in Sturmey's Scheme}

With regard to shipping, the factors that Sturmey dismisses, or at least downplays, have played a much more important role when we look at all of Western Europe and when we extend the time period to include all of the twentieth century. Table 2.3 provides a schematic overview of how the various elements developed, and how they influenced the competitiveness of European shipping. Changes in the cost structure, subsidies (and their counterpart, taxes), the transformation of the trade pattern and cargo restrictions were all important in an explanation of the European decline.

The main reason for the declining European presence in world shipping has been the combination of the general reduction in Europe's importance and the manner in which the competitive picture has shifted. During the 1950s and 1960s, the skill premium paid for European seafarers was not exorbitant, and national(istic) regulations limited the use of foreigners in most fleets. Moreover, the combination of labour-saving economies of scale, strong demand growth and frequent reinvestment in inexpensive tonnage (including efficient and value-for-money ships built in Japan) ensured that European shipping companies continued to make profits.

Europe's superior position at the start of the twentieth century, as discussed in the first section of the chapter, was largely maintained well

\footnotetext{
${ }^{28}$ Goss $(2011,246)$.

${ }^{29}$ Richard Goss interviewed in UK Parliament (1998-1999), The Environment, Transport and Regional Affairs Committee, 12th report: 'The future of the UK shipping industry'.
} 
Table 2.3 Putting the shipping trajectory into the Sturmey scheme

\begin{tabular}{lc}
\hline Factor & Effects on twentieth-century European \\
shipping
\end{tabular}

a See Ojala and Tenold (2017) for an illustration of how a handful of European countries (specifically, Greece, Norway and Denmark) have involved into 'superexporters' of shipping services, while the majority of European countries import such services from others. On Greece, see Harlaftis (1995) and Theotokas and Harlaftis (2009). For Denmark and Norway, see Sornn-Friese et al. (2012), Tenold (2012) and Tenold (2019)

into the post-war period. After the wars, the United States retreated from shipping and shipbuilding again, gradually selling off surplus tonnage, or including it in the reserve fleet, while rapidly winding down shipbuilding capacity as part of the return to a peacetime economy. Within Europe, there were changes, however. The British decline was as inevitable within shipping and shipbuilding as it had been within manufacturing - the market share was simply too large to be sustainable in the long run. Still, until 
the last part of the 1960s, the retired empire-builder controlled the world's largest fleet.

The challenge to the British market share initially came from other industrialized countries, both as a result of expanding national fleets and as a result of the increasing use of Flags of convenience by American and Greek owners, in particular. In the first post-war decades, the main competitors were found among the Traditional Maritime Nations of Europe. The cost structure of international shipping continued to favour relatively capital-abundant and technologically advanced countries that had the necessary networks and knowledge. However, in the last part of the century, this description no longer applied only to European countriesby then several Asian counties had managed to acquire the capital and skills needed to succeed in shipping. Moreover, as the centre of gravity of the world economy moved to East and Southeast Asia, networks in this region became far more important.

The political and macroeconomic forces were powerful, but European shipping companies showed a great deal of ingenuity and adaptability in order to alleviate the decline. In particular they used foreign inputs-primarily seafarers — strategically, while at the same time maintaining some functions at home. Such manoeuvres were helped by authorities that liberalized the policy regime and also introduced measures-both futile and successful—-to strengthen the countries' shipping policies. ${ }^{30}$

\section{Shipbuilding in Sturmey's Scheme}

Institutional innovations - a combination of maritime enterprise and accommodating policies — ensured that Europe maintained some of the activity within shipping. A stronger and more fundamental challenge came within shipbuilding. The UK had gradually lost market shares to other European countries from the start of the twentieth century-yards in Germany, France, the Netherlands and Scandinavia challenged Great Britain

\footnotetext{
${ }^{30} \mathrm{~A}$ good example of a futile policy is the British investment grants, which temporarily stemmed the decline of the British fleet in the late 1960s and early 1970s. These grants were costly and had no long-term effect. More successful policies have been the introduction of second registries in Norway and Denmark.
} 
through low costs, second-mover advantages, government financing and close links to 'their own' compatriot shipowners, who were often more expansive and less conservative than their British counterparts.

In the 1950 s another-and in the end far more threatening - competitor turned the shipbuilding industry on its head. Before World War II the Japanese shipbuilding industry—with a minor exception during World War I-had produced ships almost solely for the Japanese market. After the war, international demand was actively sought. Based originally on US investments and technology, Japan's shipbuilding industry expanded rapidly. ${ }^{31}$

Indirect government support, low wages and limited unionization helped the Japanese effort-a strategy that was echoed decades later in South Korea and China. In Europe in general-and in the UK shipbuilding industry in particular-high wages and frequent confrontations between workers and management had become the norm, and the combination of European sclerosis and Japanese stamina can explain the rapid transfer of orders to Japanese yards. However, it is also important to point out that the transfer of orders to Japan enabled the European shipping companies to survive- if they had been forced to buy more expensive and inferior European tonnage, they would have found it much more difficult to remain competitive.

Table 2.4 puts the development of the shipbuilding industry into the Sturmey scheme. It suggests that the shipbuilding industry was particularly suited for a transfer of production to Japan and the Newly Industrialized Countries in Asia. The technology was relatively simple. The main input - in addition to inexpensive labour — was steel, and the shipyards grew in tandem with the domestic supply of steel, ensuring an outlet for the countries' nascent steel production. At the same time, the liberal economic trading regime ensured that there were relatively few restrictions on the import of ships, effectively meaning that the whole world was a potential market for the Asian tonnage. Moreover, shipbuilding found its place within the relatively controlled economic development model seen in many Asian countries, where government directives and guided credit and currency 'nudged' the economic structure in the right direction.

\footnotetext{
31 See Blumenthal (1976), Davies (1992) or Chida and Davies (2012) for a more detailed account.
} 
Table 2.4 Putting the shipbuilding trajectory into the Sturmey scheme

\begin{tabular}{|c|c|}
\hline Factor & $\begin{array}{l}\text { Effects on twentieth-century European } \\
\text { shipbuilding }\end{array}$ \\
\hline The competitive situation/costs & $\begin{array}{l}\text { Uncompetitive labour costs in Europe and } \\
\text { standardized, easily transferable } \\
\text { technology }\end{array}$ \\
\hline Market interference & $\begin{array}{l}\text { Government attempts to stem the decline } \\
\text { (beggar-thy-neighbour in Europe) and } \\
\text { nurture infant industries (in Asia) }\end{array}$ \\
\hline \multicolumn{2}{|l|}{ Random factors } \\
\hline Wars & $\begin{array}{l}\text { Cold War support helped South Korean and } \\
\text { Japanese industrialization and } \\
\text { capacity-building }\end{array}$ \\
\hline Changes in the trade pattern & $\begin{array}{l}\text { Improved communication reduced the } \\
\text { 'home bias', that is, the advantage of } \\
\text { proximity between shipowners and yards }\end{array}$ \\
\hline Taxation & $\begin{array}{l}\text { Subsidies (negative taxation) have been } \\
\text { important; defensive support in Europe, } \\
\text { offensive support in Asia }\end{array}$ \\
\hline Non-shipbuilding policies & $\begin{array}{l}\text { Credit, currency, employment and } \\
\text { unemployment policies have facilitated } \\
\text { the growth, as well as industrial policies }\end{array}$ \\
\hline Internal constraints & $\begin{array}{l}\text { Reliance on government support, even in } \\
\text { the growth phase }\end{array}$ \\
\hline
\end{tabular}

The main reason for the decline of European shipbuilding was the change in the competitive situation. With labour costs such a large part of the picture, and a technology that was easy to transfer, European shipyards were unable to compete. Even generous public support-countercyclical subsidies to deal with a structural crisis-was unable to do more than stem the decline in the orders for large ships. Although Europe still has an important position in certain shipbuilding niches, the high-volume production has disappeared.

The analyses above have illustrated that while the European conditions for both shipping and shipbuilding deteriorated, shipping companies were able to adapt to the new competitive situation in a way that shipyards could not. 


\section{When Did Europe Lose Its Maritime Hegemony?}

The analysis of the declining role of European shipping and shipbuilding in the twentieth century suggests the following broad pictures. Within shipping, Europe gradually lost its position, with particularly large temporary drops during the two world wars. Moreover, in the period from around the middle of the 1970s, the decline accelerated. In the last quarter of the century there was a pronounced relative reduction; the European-registered share of the world fleet fell rapidly. However, part of the declining market share was offset by European-owned ships flying foreign flags, which are hard to identify in the data.

In shipbuilding, there was a more or less continuous British loss of market share, initially taken over by other European countries, then by Japan as well. The continental European competitiveness evaporated in tandem with the new orders after 1975, and shipyards were forced to rapidly reduce their productive capacity. For a while, governments supported the industry, recognizing neither the structural shift nor how the potential for competitive high-volume shipbuilding in Europe had disappeared.

Why was the 1970 s such a watershed? It could be argued that this decade was a turning point for Europe in general. The end of the Golden Age and the deepening Eurosclerosis was the local part of the story. This was exacerbated by concerted — and successful —efforts at economic modernization in a number of Asian countries, including China, where Deng Xiaoping started crossing the river 'one stone at the time'. The sheer number of people - and the potential increases in income-meant that the Asian advances, if successful, would overwhelm the international economy.

The turning point-where the downward-sloping trend began to accelerate-was the OPEC-orchestrated oil price increases of the 1970s. These triggered an unprecedented crisis in shipping and shipbuilding. As a result, the European decline picked up speed — tonnage was transferred to foreign flags and shipyards were closed. From 1973 to 1987 the British-flagged fleet declined by more than $75 \%$, as did the fleets of Norway and Sweden. 
Over the same period, the fleets of the main Flags of convenience doubled, while the five leading Asian nations (except Japan) saw their fleets multiply by a factor of more than seven. ${ }^{32}$

The collapse was just as severe in shipbuilding. Due to the lag between ordering and delivery, the European deliveries peaked a couple of years after the shipping market had collapsed. In 1975, shipyards in Europe delivered more than 14 million gross tons. Ten years later, the figure was 3.6 million tons and the trend continued downwards-'European shipbuilding production never recovered to the pre-crisis level'. ${ }^{33}$

Governments in Europe initially attempted to support European yards in the anticipation that the downturn was temporary. The shipyards were more pragmatic: as European shipbuilding was gradually being built down, the scraps were sold abroad. For instance, the world's largest shipbuilder-Hyundai Heavy Industries - entered shipbuilding on the basis of South Korean determination and labour, but with crucial contributions from European capital (credit) and competence (technology and consultancy). ${ }^{34}$

In shipping, the shift from growth to stagnation in demand led to a new focus on costs, and ushered in a number of technological and institutional innovations. The crisis forced shipowners to cut costs wherever possible, and although manning costs had become a very small proportion of total costs, paying four to five times as much for labour as the competitors still made a difference. ${ }^{35}$ Moreover, the types of businesses engaged in the industry changed, with myopic speculators and financial investors taking the place of the old traditional 'shipowners', who had a long-term view both on their business and on its role in the local maritime community.

Both within shipping and shipbuilding, the European decline was taken to the extreme in the case of the UK. As Sarah Palmer points out, the downfall was not a gradual process; there was a loss of market shares in the

\footnotetext{
${ }^{32}$ See the analysis in Tenold $(2006,92-101)$. The term 'Flags of convenience' refers to Bahamas, Bermuda, Cyprus, Liberia and Panama, while the five rapidly growing Asian fleets are those of China, Hong Kong, The Philippines, Singapore and South Korea.

${ }^{33} \mathrm{OECD}(2017,52)$.

${ }^{34}$ See Kang et al. $(2015,2016)$.

35 Awkwardly, despite the current universal use of labour from low-cost countries, a lot of research funding is spent on 'crew-less ship design'. For a 165,000 ton container ship, valued at some 175 million USD, even a crew of thirteen Filipinos appears to be too expensive.
} 
first part of the century, but after 1975 'the UK flagged fleet [...] went into free fall'. ${ }^{36}$ British shipbuilding, which had been even more dominant, was at the end of the century 'reduced to rump status in international terms and struggling for its very existence. ${ }^{37}$ By the end of the century, merchant shipbuilding had 'all but ended' in the United Kingdom. ${ }^{38}$

\section{Conclusion: Was Western Europe Doomed to Lose Its Maritime Hegemony?}

Inequalities in economic development-an industrialized and politically dominant Europe and a relatively underdeveloped periphery_can explain the European/Western leadership in shipping and shipbuilding at the start of the twentieth century. Europe had the capital and competence necessary to gain and maintain the maritime hegemony. The hegemony was — rightly or wrongly — a reflection of Europe's leading position within international trade, manufacturing production and global politics.

The maritime industries were particularly vulnerable to competition. The reason is simple: despite improvements in communications, there are still transport and transaction costs in most industries, although they are low compared with previous times. In international shipping and shipbuilding, however, such costs are largely irrelevant, as 'mobility' is the fundamental aspect of the product. It is extremely difficult to tax and to regulate objects that can easily be moved from one jurisdiction to another.

The term 'globalization', at least in its economic guise, is often depicted as a process where relations between nations are tightened and international trade and investment increase. However, in addition to the growth in general terms, this process may entail a significant element of dislocation. Like customs unions have both a trade creating and a trade diverting effect, 'globalization' has had both a production creating and a production diverting effect. In the case of shipping and shipbuilding, activities and

\footnotetext{
36 Palmer (2012, 124); see also Palmer (2008).

${ }^{37}$ Johnman and Murphy (2002, 244).

${ }^{38}$ Buxton et al. $(2015,305)$.
} 
production have been transferred from Europe to other parts of the world, in particular to East and Southeast Asia.

The net effect for Europe has varied among the different types of activities. In shipbuilding, there has been a substantial decrease in activity in European yards since the peak in the middle of the 1970s, particularly with regard to the construction of the largest tankers and dry bulk ships. In most European countries, the number of merchant ships under construction has declined, and in terms of tonnage, the reduction has been even more spectacular.

Within shipping, there has also been a substantial loss in the European market share during the twentieth century, with an acceleration in the last quarter. However, the European position was 'abnormally high' at the start of the century-Western Europe had around 15\% of world population, but controlled more than $85 \%$ of the world fleet in 1900. Moreover, even though the market share has declined, the European tonnage has increased substantially - the production creation has been higher than the production diversion.

Despite this growth, Europe's development in shipping and shipbuilding is one of relative decline. The undisputable leader at the start of the century-Great Britain-has been hit harder than most. In 1988, the Transport Committee of the UK Parliament recognized that the British shipping industry had 'declined to such an extent that action was needed to remedy the situation'. Despite political efforts, ten years later the very same committee acknowledged that 'the industry's decline has continued'. ${ }^{39}$

The nineteenth century was characterized by the dominance of Europe in general, and the UK in particular, in international politics and trade. During the twentieth century, the world became more balanced-the European leadership disappeared as new regions were integrated into the world economy. Nevertheless, for most of the century, Europe determined the direction and the speed of international shipping and shipbuilding. The Japanese challenge started in earnest in the 1950s, but it was not until the last decades that the Europeans were replaced by Asians within

\footnotetext{
39 UK Parliament (1998-1999), The Environment, Transport and Regional Affairs Committee, 12th report: 'The future of the UK shipping industry'. The reference in the 1998 report is to UK Parliament (1987-1988) Transport Committee, First report: 'Decline in the UK-registered merchant fleet'.
} 
shipbuilding. The conditions for modern, low-cost production are much better in Japan, South Korea and China, and the technology was easy to transfer.

By the end of the twentieth century, Europe's commercial and political networks were no longer the quasi-monopolies they had been at the start of the century. Faced with increased foreign competition, European shipping companies managed to remain profitable by reducing the European contents of their services, moving to low-tax flags and utilizing low-cost labour from Asia. At the same time, some activities remained in Europe, though the market share was lower than before. Consequently, due to the slicing up of the value chain within shipping, it is difficult to determine the true nationality of a ship or a shipping company. A global, often unidentifiable, fleet has become the norm.

The growing share of Asia in world production and trade has been one of the most important developments in the international economy after the Second World War. Developments in shipping and shipbuilding made this integration possible. The European hegemony had been based on a combination of technological leadership, superior investment capacity and skill and knowledge advantages. It was unlikely to last.

\section{References}

Berglund, A. (1926). Our Merchant Marine Problem and International Trade Policies. Journal of Political Economy, 34(5), 642-656.

Blumenthal, T. (1976). The Japanese Shipbuilding Industry. In H. Patrick $\&$ L. Meissner (Eds.), Japanese Industrialization and Its Social Consequences (pp. 129-160). Berkeley: University of California Press.

Boyce, G. (1995). Information, Mediation and Institutional Development: The Rise of Large-Scale Enterprise in British Shipping, 1870-1919. Manchester: Manchester University Press.

Boyce, G. (2012a). The Development of Commercial Infrastructure for World Shipping. In G. Harlaftis, S. Tenold, \& J. M. Valdaliso (Eds.), The World's Key Industry-History and Economics of International Shipping (pp. 106-123). Basingstoke: Palgrave Macmillan. 
Boyce, G. (2012b). The Growth and Dissolution of a Large-Scale Business Enterprise: The Furness Interest, 1892-1912. St. John's: IMEHA.

Buxton, I., Fenton, R., \& Murphy, H. (2015). Measuring Britain's Merchant Shipbuilding Output in the Twentieth Century. The Mariner's Mirror, 101(3), 304-322.

Chida, T., \& Davies, P. (1990/2012). The Japanese Shipping and Shipbuilding Industries-A History of Their Modern Growth. London and New York: Bloomsbury.

Davies, P. (1992). The Role of National Bulk Carriers in the Advance of Shipbuilding Technology in Post-war Japan. The International Journal of Maritime History, 4(1), 131-142.

Davies, P. (2008). A Guide to the Emergence of Japan's Modern Shipping Industries. In L. R. Fischer \& E. Lange (Eds.), International Merchant Shipping in the Nineteenth and Twentieth Centuries (pp. 105-124). St. John's: IMEHA. ECORYS. (2009). Study on Competitiveness of the European Shipbuilding Industry. Rotterdam: ECORYS.

Goss, R. O. (2011). Strategies in British Shipping, 1945-1970. The Mariner's Mirror, 97(1), 243-258.

Harlaftis, G. (1995). A History of Greek-Owned Shipping: The Making of an International Tramp Fleet, 1830 to the Present Day. London: Taylor \& Francis. Ingram, P., \& Lifschitz, A. (2006). Kinship in the Shadow of the Corporation: The Interbuilder Network in Clyde River Shipbuilding, 1711-1990. American Sociological Review, 71(2), 334-352.

Jamieson, A. (2003). Ebb Tide in the British Maritime Industries: Change and Adaptation, 1918-1990. Liverpool: Liverpool University Press.

Johnman, L., \& Murphy, H. (2002). British Shipbuilding and the State Since 1918-A Political Economy of Decline. Exeter: University of Exeter Press.

Kang, J. Y., Kim, S., Murphy, H., \& Tenold, S. (2015). Old Methods Versus New: A Comparison of Very Large Crude Carrier Construction at Scott Lithgow and Hyundai Heavy Industries, 1970-1977. Mariner's Mirror, 101(4), 426-457. Kang, J. Y., Kim, S., Murphy, H., \& Tenold, S. (2016). British Financial, Managerial and Technical Assistance in Establishing the Global Shipbuilding Giant, Hyundai Heavy Industries. The International Journal of Maritime History, 28(1), 81-101.

Kenwood, A. G., \& Lougheed, A. L. (1999). The Growth of the International Economy 1820-2000. London: Routledge.

Lorenz, E. H. (1991). An Evolutionary Explanation for Competitive Decline: The British Shipbuilding Industry, 1890-1970. The Journal of Economic History, 51(4), 911-935. 
Milne, G. J. (2009). North East England Shipping in the 1890s: Investment and Entrepreneurship. The International Journal of Maritime History, 21(1), 1-26. OECD. (2017). Imbalances in the Shipbuilding Industry and Assessment of Policy Responses (C/WP6(2016)6/FINAL). Paris: OECD Working Party on Shipbuilding.

Ojala, J., \& Tenold. S. (2017). Maritime Trade and Merchant Shipping: The Shipping/Trade Ratio Since the 1870s. The International Journal of Maritime History, 29, 838-854.

Palmer, S. (2008). British Shipping from the Late Nineteenth Century to the Present. In L. R. Fischer \& E. Lange (Eds.), International Merchant Shipping in the Nineteenth and Twentieth Centuries (pp. 125-142). St. John's: IMEHA. Palmer, S. (2012). Government and the British Shipping Industry in the Later Twentieth Century. In G. Harlaftis, S. Tenold, \& J. M. Valdaliso (Eds.), The World's Key Industry-History and Economics of International Shipping (pp. 124-141). Basingstoke: Palgrave Macmillan.

Pollard, S. (1957). British and World Shipbuilding, 1890-1914: A Study in Comparative Costs. The Journal of Economic History, 17(3), 426-444.

Robertson, P. L. (1974). Shipping and Shipbuilding: The Case of William Denny and Brothers. Business History, 16(1), 36-47.

Scholl, L. U. (1998). The Global Communication Industry and Its Impact on International Shipping Before 1914. In D. J. Starkey \& G. Harlaftis (Eds.), Global Markets: The Internationalization of the Sea Transport Industries Since 1850 (pp. 195-215). St. John's: IMEHA.

Schwarz, T., \& von Halle, E. L. (1902). Schiffbauindustrie in Deutschland und im Auslande. Berlin: Mittler.

Slaven, A. (2013). British Shipbuilding: A History 1500-2010. Lancaster: Crucible Books.

Sornn-Friese, H., Poulsen, R. T., \& Iversen, M. J. (2012). "Knowing the Ropes": Capability Reconfiguration and Restructuring of the Danish Shipping Industry. In S. Tenold, M. J. Iversen, \& E. Lange (Eds.), Global Shipping in Small Nations-Nordic Experiences After 1960 (pp. 61-99). Basingstoke: Palgrave Macmillan.

Statistics Norway. (1902). Statistisk aarbog for kongeriget Norge (pp. 168-169). Kristiania: Det Statistiske Centralbureau and H. Aschehoug \& Co, Tables I and $\mathrm{K}$.

Sturmey, S. G. (1962/2010). British Shipping and World Competition. St. John's: IMEHA.

Tenold, S. (2006). Tankers in Trouble-Norwegian Shipping and the Crisis of the 1970s and 1980s. St. Johns: IMEHA. 
Tenold, S. (2012). Boom, Crisis and Internationalised Revitalisation: Norwegian Shipping 1960-2008. In S. Tenold, M. J. Iversen, \& E. Lange (Eds.), Global Shipping in Small Nations-Nordic Experiences After 1960 (pp. 26-60). Basingstoke: Palgrave Macmillan.

Tenold, S. (2019). Norwegian Shipping in the 20th Century-Norway's Successful Navigation of the World's Most Global Industry. Cham: Palgrave Macmillan. Theotokas, I., \& Harlaftis, G. (2009). Leadership in World Shipping: Greek Family Firms in International Business. Basingstoke: Palgrave Macmillan.

Todd, D. (2011). Going East: Was the Shift in Volume Shipbuilding Capacity from Britain and Continental Europe to the Far East and Elsewhere During the Latter Half of the Twentieth Century Inevitable? The Mariner's Mirror, 97(1), 259-271.

Yates, P. L. (1959). Forty Years of Foreign Trade: A Statistical Handbook with Special Reference to Primary Products and Under-developed Countries. London: Allen \& Unwin.

Open Access This chapter is licensed under the terms of the Creative Commons Attribution-NonCommercial-NoDerivatives 4.0 International License (http:// creativecommons.org/licenses/by-nc-nd/4.0/), which permits any noncommercial use, sharing, distribution and reproduction in any medium or format, as long as you give appropriate credit to the original author(s) and the source, provide a link to the Creative Commons license and indicate if you modified the licensed material. You do not have permission under this license to share adapted material derived from this chapter or parts of it.

The images or other third party material in this chapter are included in the chapter's Creative Commons license, unless indicated otherwise in a credit line to the material. If material is not included in the chapter's Creative Commons license and your intended use is not permitted by statutory regulation or exceeds the permitted use, you will need to obtain permission directly from the copyright holder. 